Original article / Orijinalaraştırma

\title{
Comparison of antigen and antibody detection tests used for diagnosing the Helicobacter pylori infection in symptomatic patients
}

\author{
Semptomlu hastalarda Helicobacter pylori enfeksiyonu tanısında \\ kullanılan antijen ve antikor tarama testlerinin karşılaştırılması \\ Ahmet Alim ${ }^{1}$, Mehmet Ataş ${ }^{1}$, Turabi Güneş ${ }^{2}$, Suzan Özkan ${ }^{3}$, Nilgün Dündar ${ }^{4}$ \\ ${ }^{1}$ Public Health Laboratory, Sivas Health Directorate, ${ }^{2}$ Health Services Vocational \\ College, Cumhuriyet University, ${ }^{3}$ Department of Nursing, Cumhuriyet University Faculty \\ of Health Sciences, ${ }^{4}$ Sivas Health Directorate, Sivas
}

\begin{abstract}
Helicobacter pylori (H. pylori) infection is usually acquired in early childhood. H. pylori infection can be diagnosed by noninvasive techniques (serology, urea breath test, urine or blood, detection of $H$. pylori antigen in stool specimen) and by invasive techniques requiring endoscopy and biopsy (histological examination, culture, polymerase chain reaction). Recently, fecal antigen testing has been used successfully for the diagnosis of $H$. pylori infection in the Symptomatic Patients. We compared H. pylori fecal antigen and immunoglobulin $\mathrm{G}$ ( $\mathrm{gGG}$ ) serologic diagnostic methods in a population of symptomatic patients with $H$. pylori infection. The tests were performed with enzyme immunoassay (ELISA). All specimens were collected between January and October 2009 from 27 health center in Sivas-Turkey. The presence of clinical symptoms, such as dyspepsia and abdominal pain, was determined. A total of 705 patients were studied. Totally, 534 women (mean age 38.2) and 171 men (mean age 41.9) in this epidemiological investigation were enrolled. The $H$. pylori fecal antigen was positive in the stool specimens of 209 patients $(29.6 \%)$ and the $H$. pylori IgG test was positive in the serum specimens of $487(69.0 \%)$ patients. The fecoprevalance and seroprevalence of $H$. pylori infection were higher in women than in men $(p<0.05)$. ELISA fecal antigen testing is a practical and feasible alternative to traditional invasive diagnostic methods in highprevalence populations. The fecal antigen test can also be used to establish cure of $H$. pylori infection.
\end{abstract}

\footnotetext{
${ }^{1}$ Corresponding author:

Dr. Ahmet Alim, Halk Sağlığı Laboratuvarı, MevlanaCaddesi, Sivas.

Email: alim58@gmail.com
} 
Key words: Helicobacter pylori, fecal antigen test, serum antibody test

\section{Özet}

Helicobacter pylori (H. pylori) enfeksiyonu genellikle erken çocukluk döneminde kazanılır. H. pylori enfeksiyonuna noninvaziv yöntemler (seroloji, üre nefes testi, idrar, kan veya dışkıda $H$. pylori antijeni varlığı) ve invaziv yöntemler gerektiren endoskopi ve biyopsi (histolojik inceleme, kültür, polimeraz zincir reaksiyonu) ile tanı konulabilir. Son zamanlarda, semptomlu hastalarda $H$. pylori enfeksiyonu tanısı için dışkıda antijen testi başarıyla kullanılmaktadır. Çalışmamızda, H. pylori enfeksiyonu ön tanısı konulmuş olan semptomlu hastalarda $H$. pylori dışkıda antijen ve immünglobulin $G$ (IgG) serolojik tanı yöntemleri karşılaştırılmıştır. Testler enzim immünassay (ELISA) yöntemi ile çalışılmıştır. Bu çalışmadaki bütün örnekler Ocak-Ekim 2009 tarihleri arasında, Sivas'ta bulunan ve birinci basamak sağık hizmeti veren 27 sağlık merkezinden toplanmıştır. Hastalarda dispepsi ve karın ağrısı gibi klinik belirtilerin varlığı tespit edilmiştir. Çalışmanın tamamı 705 hasta üzerinde yapılmıştır. Toplamda, 534 kadın (yaş ortalaması 38,2) ve 171 erkek (yaş ortalaması 41,9) hasta bu epidemiyolojik araştırmaya dahil edilmiştir. Dışkı örneklerinin 209'unda $(\% 29,6) \mathrm{H}$. pylori dışkıda antijen testi ve serum örneklerinin de 487'sinde $(\% 69,0) H$. pylori IgG testi pozitif bulunmuştur. H. pylori fecoprevalansı ve seroprevalansı kadınlarda erkeklerde göre daha yüksek bulunmuştur $(p<0,05)$.ELISA fekal antijen testi yüksek prevalansa sahip toplumlarda, geleneksel invaziv tanı yöntemleri içerisinde pratik ve uygulanabilir bir alternatif yöntemdir. H. pylori fekal antijen testi, enfeksiyonun tedavisini kanıtlamak için de kullanılabilir.

Anahtar sözcükler: Helicobacter pylori, dışkıda antijen testi, serumda antikor testi

\section{Introduction}

Almost $50 \%$ of the world population is infected with Helicobacter pylori (H. pylori). Nevertheless, many people continue their life asymptomatically (1). There is a relation between the $H$. pylori infection and the pathogenesis of peptic ulcer disease (2).

This bacterium is a gram-negative, microaerophilic and a urease-generating microorganism which is capable of colonizing in gastric mucosa and staying here for a long time (3). H. pylori inhabits between the gastric epithelial cell surface and the mucus layer covering it (4). $\mathrm{pH}$ is 1.0-2.0 in the stomach lumen, whereas it is around 7.4 under the mucus (5). H. pylori and non-steroid anti-inflammatory drugs are the two most important factors causing peptic ulcer development and ulcer complications as hemorrhage (6). Upper gastrointestinal system (UGS) hemorrhages are a significant mortality and morbidity cause and seen in 80-100 of 100.000 people in the society (7). Eradication of $H$. pylori reduces ulcer relapse and repeated hemorrhages due to peptic ulcer (8). When $\mathrm{H}$. pylori is not eradicated, the repeated hemorrhage rate is $30 \%$ within 1-2 years and this rate goes down to $1-2 \%$ in the people eradication is provided for. Consequently, for the approach to upper GIS hemorrhages, eradication of H. pylori is an important requirement (9). 
Due to the lack of golden standard yet, the tests based on biopsy are still used as the reference method for diagnosing $H$. pylori infections and following the eradication treatment (10). H. pylori is a bacterium which is proven to cause the development of chronic superficial gastritis, chronic active gastritis, duodenal ulceration, adenocarcinoma developed after chronic gastritis, gastric non-Hodgkin lymphoma and gastric mucosal lymphoid tissue lymphoma in human (11). H. pylori is proclaimed first degree carcinogen by the World Health Organization (WHO). It is stated that $H$. pylori increases the risk of stomach cancer by six times (12-16). Especially for the patients with peptic ulcer, doing test is a must (17). For this purpose, a large number of diagnostic tests (invasive and non-invasive) have been developed.

In this study, it is aimed for the comparison of antigen and antibody detection tests commonly used for the serological diagnosis of $H$. pylori at the symptomatic patients applying to the primary healthcare facilities as a result of complaints related to stomach disorders, acute chronic gastritis, peptic ulcer (duodenal ulcer) and stomach cancer.

\section{Material and Methods}

This study was carried out at 27 healthcare facilities providing primary healthcare service in Sivas Provincial Centre between January and October 2009. At symptomatic patients applying to the healthcare facilities as a result of complaints related to stomach disorders, acute chronic gastritis, peptic ulcer (duodenal ulcer) and stomach cancer, antigen (in stool) and antibody (in blood serum) detection tests commonly used at many healthcare facilities for the serological diagnosis of $\mathrm{H}$. pylori were used together.

Of 705 people participated in our study, 534 (75.7\%) were women and 171 (24.3\%) were men. All of the participants were consisted of persons at the age range of 15-83 and they all accepted to participate in the study. The average age was established as $38.2 \pm 12.9$ years in women and $41.9 \pm 16.3$ years in men. The participation approval of 39 persons, who were under 18, among the patients participated in the study were obtained from their parents (required by Helsinki Declaration) and then their demographic data were further recorded together with their signed participation forms.

From each patient, $5 \mathrm{ml}$ blood sample was taken into the sterile gel-vacuum tubes in order to use for antibody detection and the taken samples were brought to Public Health Laboratory under cold chain conditions. The samples serum of which was separated were stored at $-20^{\circ} \mathrm{C}$ until the study time. Likewise, approximately 1-1.5 g of stool samples was taken from the patients for antigen detection into the spin-top, spoon-cover and outer-labeled stool containers. The stool samples were transported to the Public Health Laboratory through a special motorized courier quickly by following the cold chain condition as the blood samples. For the blood serum samples, it was paid great attention to study as they arrived without keeping waited. By keeping stool samples waited at $-20^{\circ} \mathrm{C}$, all of the samples were hold at the laboratory to be complete and then the study was performed. 
In blood serum samples, H. pylori IgG type antibody was searched. All of the bloods taken were studied under ELISA method and the results were recorded individually. The ELISA kit we used (Orgenics ${ }^{\circledR}$ Immunocomb II) was a test which did not require any equipment to study, was suitable for single study, very easy to use, had a sensitivity of $95.8 \%$ and specificity of $76 \%$, worked according to the principle of indirect solid phase dot-ELISA, qualitative, had an internal control and sensitive to measure at least $20 \mathrm{lU} / \mathrm{ml}$ H. pylori IgG found in the serum. From each serum sample, $10 \mu \mathrm{L}$ was taken and diluted with $100 \mu \mathrm{L}$ diluent and $25 \mu \mathrm{L}$ was taken from the diluted samples and the study was commenced in accordance with the prospectus of the kit. The results were evaluated visually.

All of the stool samples, $H$. pylori antigen was searched. The commercial kit used for antigen detection was a test working with ELISA method (Premier Platinum HpSA, Meridian Diagnostics ${ }^{\circledR}$ Inc. Cincinnati, Ohio, USA), giving qualitative results and having an internal control. The sensitivity of the test is $96.1 \%$ and the specificity is $95.7 \%$. In this test, wells containing polyclonal rabbit anti- $H$. pylori antibodies were used. $100 \mu$ l was taken from the diluted stool samples and studied $(10 \mu \mathrm{l}$ of stool, $0.5 \mathrm{ml}$ of sample diluent). The study was performed in accordance with the recommended prospectus of the commercial kit. Results of the study were read at a spectrophotometer under 450 $\mathrm{nm}$ and the results higher than 0.140 were considered as positive. Both of the tests were preferred due to the ease of use at the field searches. The suspicious samples in the studies made by both methods were evaluated and studied again.

Data were expressed as percentages and analyzed with chi-square test. A p value of less than 0.05 was considered as significant.

\section{Results}

H. pylori IgG antibody was found positive in 487 (69.0\%) of the blood serums of 705 patients taken into the study, whereas found negative in 218 (31.0\%) (Table 1). When the distribution of these results according to the gender was analyzed, it was found that the positivity rate in women $(71.2 \%)$ was higher than in men $(59.6 \%)(p<0.05)$. Likewise, the negativity rate $(40.4 \%)$ in men was found to be higher than in women $(27.9 \%)(p<0.05)$. A statistically significant difference was found between the percentage distribution rates of antibody positivity in blood according to gender $(p<0.05)$.

It was found that the positivity rates in the studies made for identifying $H$. pylori antigen in stool were lower than the previous antibody positivity rates (Table 2). Antigen was detected in stool in 209 (29.6\%) of total 705 persons, whereas antigen could not be detected in 496 persons (70.4\%). When the distribution of antigen positivity according to gender is analyzed, it was found that the positivity rates of women (34.3\%) were higher than men $(21.0 \%)(p<0.05)$. Similarly, the antigen finding negativity in stool was lower in women $(65.7 \%)$ and higher in men $(79.0 \%)(p<0.05)$. A statistically significant difference was found between the percentage distribution rates of antibody positivity in blood according to gender $(p<0.05)$. 
Table 1.Evaluation results of antibody in the blood (H. pylori lgG).

\begin{tabular}{|l|l|l|l|}
\hline & $\begin{array}{l}\text { Positive } \\
\mathrm{n}(\%)\end{array}$ & $\begin{array}{l}\text { Negative } \\
\mathrm{n}(\%)\end{array}$ & $\begin{array}{l}\text { Total } \\
\mathrm{n}\end{array}$ \\
\hline Women & $385(72.1)$ & $149(27.9)$ & 534 \\
\hline Men & $102(59.6)$ & $69(40.4)$ & 171 \\
\hline Total & $487(69.0)$ & $218(31.0)$ & $705(100.0)$ \\
\hline $\mathrm{p}<0.05$ & & \\
\hline
\end{tabular}

Table 2.Evaluation results of stool antigen (H. pylori).

\begin{tabular}{|l|l|l|l|}
\hline & $\begin{array}{l}\text { Positive } \\
\mathrm{n}(\%)\end{array}$ & $\begin{array}{l}\text { Negative } \\
\mathrm{n}(\%)\end{array}$ & $\begin{array}{l}\text { Total } \\
\mathrm{n}\end{array}$ \\
\hline Women & $183(34.3)$ & $351(65.7)$ & 534 \\
\hline Men & $36(21.0)$ & $135(79.0)$ & 171 \\
\hline Total & $209(29.6)$ & $496(70.4)$ & $705(100.0)$ \\
\hline $\mathrm{p}<0.05$ & & \\
\hline
\end{tabular}

When the positivity rates of both tests are compared, it is found that the positivity rate at antibody detection in blood is higher than antigen detection in stool (Table 3). Similarly, when the negativity rates are compared, it is found that the negativity rate at antigen detection in stool is higher than antibody detection in blood. When the status of both tests in terms of positivity was considered, no statistically significant difference was found in between $(p<0.05)$.

Table 3.Evaluation of the results of the test together every two.

\begin{tabular}{|l|l|l|l|}
\hline & $\begin{array}{l}\text { Positive } \\
\mathrm{n}(\%)\end{array}$ & $\begin{array}{l}\text { Negative } \\
\mathrm{n}(\%)\end{array}$ & $\begin{array}{l}\text { Total } \\
\mathrm{n}\end{array}$ \\
\hline Antibody in the blood & $487(69.0)$ & $218(31.0)$ & 705 \\
\hline Stool Antigen & $209(29.6)$ & $496(70.4)$ & 705 \\
\hline $\mathrm{p}<0.05$ & & \\
\hline
\end{tabular}

In our study, it is found that the positivity rates in both tests increase correspondingly as the number of siblings and the number of family members increases (five or more family members). However, no statistically significant difference was found in between $(p>0.05)$.

\section{Discussion}

H. pylori infections are an important public health issue in our country as it is in all developed and developing countries. Many studies performed at home and abroad indicate that $H$. pylori is the cause of several diseases that can progress to stomach cancer, especially chronic gastritis and peptic ulcer disease (gastric and duodenal ulcer)(18-21). In H. pylori-infected patients, first IgM class antibodies develop. Then, both systematically and locally in gastric mucosa, IgG and IgA antibodies develop and the level of these two antibodies can be maintained for months-years (22). IgG seropositivity may continue for 3 years, even proper antibiotics are used (17). If proper 
antibiotics are not used, antibodies in the structure of IgA and IgG react with the germ antigens on the cell surface and cause an autoimmune respond and tissue damage (23). Microorganism first causes an acute gastritis in the mucosa and then the gastritis turns into chronic gastritis and gastric atrophy (gastric gland loss along with various degrees of intestinal metaplasia) during a slow process of 20-40 years (24).

In our study, blood serum and stool samples of total 705 patients who were prediagnosed with $H$. pylori were analyzed. In this analysis made, regarding the distribution of $H$. pylori antibody rate in blood and antigen rate in stool according to gender, it was found that the distribution in women was significantly higher than men. And in the collective evaluation of both tests, it was found that the positivity rate was higher in men and there was a significant difference in between (Table 3). One of the reasons for the $H$. pylori IgG seropositivity being higher than antigen detection in our study is the IgG antibody positivity ongoing in the serum (almost 3 years).

A study similar to our study was performed by Naous et al.(19) in Lebanon and indicated that the antigen positivity rates in stool statistically increased in cases like low socioeconomic status and increase in the number of family members. And the studies by Perry et al. performed in USA support this thesis, too (25). Gulcan et al.(26) detect antigen with ELISA in stool in 48 of 49 patients, who were diagnosed with various methods, in a study carried out in Istanbul. They evaluated this phenomenon as false positive.

In another study of 40 cases, carried out at Dokuz Eylul University Faculty of Medicine (27), H. pylori antigen in stool-ELISA and Simple H. pylori single step antigen cassette test were compared. In the study, the sensitivity of pre-treatment $H$. pylori antigen in stoolELISA was found $74.3 \%$, whereas the sensitivity of cassette test was $87 \%$. No statistically significant difference was found between the results.

Furthermore, in a large-scaled serology study carried out in Canada, false-positivity was found at the rate of $33 \%$ in the clinical tests made at primary healthcare units (28). In a study made on 102 dyspeptic children in Turkey recently (29), sensitivity of only $71.9 \%$ was found for serology. Differently from these findings, in another study involving 180 children (15), $100 \%$ sensitivity and $98 \%$ specificity were found (30).

Selection of a diagnostic test should depend on the clinical conditions, sensitivity, specificity, cost and availability of the test. Serology is a commonly used, inexpensive and non-invasive method. The advantage of serological tests is that they can be applied by many hospitals and clinical laboratories without the need for any special equipment or technique. And the most important disadvantage of the serological tests is that they cannot distinguish the difference between an active infection and a previously-had infection. Although some insufficient quantitative tests have affected the reputation of serology negatively, it should not be forgotten that the best results are obtained with quantitative antibody tests that can be compared to the urea breath test for the primary diagnosis of $H$. pylori infection (31). Additionally, there are studies indicating that 
serology is specifically superior to invasive methods at the patients with serious atrophic gastritis (32).

A similar study was carried out by Konstantopoulos et al.(33) in Germany and they detected $H$. pylori antigen in stool in $96(66.2 \%)$ of 145 symptomatic children. In the same study, it was reported that the antigen in stool test was more proper for following H. pylori treatment healthily. Cherian et al.(34) analyzed 193 children in terms of antigen in stool and also antibody positivity in blood in a society with high prevalence for $\mathrm{H}$. pylori in Africa and found a positivity at the rate of approximately $81.9 \%$. In this study, it was suggested that the antibody detection in blood was not sufficiently useful for diagnosing the patient. In a study by Agha et al.(35) made in Germany, it was reported that when antigen was searched with ELISA method in stool samples of 54 patients diagnosed with $H$. pylori by endoscopy and biopsy, false negativity was obtained only in one patient and positivity was obtained in 53 patients.

In a study (36) made in China recently, as it is in our study, it was concluded that serum antibody levels were not enough to understand either the seriousness of the gastrointestinal disease or the degree of histopathological intensity at $H$. pylori infected patients. It is known that the antigen in stool test is useful in epidemiological field studies (37). Antibody in blood tests are useful for the patients who have never had treatment before, but give no information if the infection is active or terminated at the the patients who have had treatment. Many studies have revealed that the antigen in stool test is useful after the antibiotic treatment (2).

Invasive tests; culture, histology, rapid urease test and PCR, are not used frequently at every patient and under every hospital condition because they are based on biopsy. And non-invasive tests; urea breath test and ELISA tests intended for searching $H$. pylori antigen in stool samples, are used frequently because there is no need for endoscopy and they have a sensitivity and specificity that is very close to the culture tests accepted as the golden standard. It is accepted that ELISA H. pylori antigen detection in stool test is a good non-invasive test for the diagnosis of $H$. pylori infection $(38,39)$.

As the information on $\mathrm{H}$. pylori increase, the advances in respect of diagnostic tests also increase correspondingly. Histology, urea breath test and culture like invasive tests are based on biopsy and may be considered expensive or require endoscopy that may not be tolerated by some patients and as a consequence, non-invasive tests are preferred frequently. There is not only one golden standard among the diagnostic tests and contrary to the practice made in the scientific papers, use of many different diagnostic tests for achieving more reliable test results would not be a realistic approach. In addition to these, the great effect of the factors such as the regional prevalence of the infection on the predictive values of the tests used has raised the regional importance of diagnostic tests (40).

There is no significant difference between the $H$. pylori antigen in stool test that we have used in the study and other ELISA tests detecting antigen in stool. It can be used at 
diagnosis and follow-up securely. It is also a suitable test for prevalence tests, too. The antibody detection in blood serum test that we have used for $\mathrm{H}$. pylori diagnosis in our study is from the rapid, simple, non-invasive, standardized, low-specificity and highsensitivity tests. In countries, where the H. pylori prevalence is high, like Turkey, antibody detection in blood serum test should not be used for diagnosing acute infection through qualitative values. If it will be used, titration increase or decrease should be followed.

\section{Conflicts of interest}

The authors have no conflicts of interest to declare.

\section{References}

1. Benjamin DG, Richard BC, Myles A, et al. Helicobacter pylori Infection in Children: Recommendations for Diagnosis and Treatment. J Pediatr Gastroenterol Nutr 2000; 31: 490-7.

2. Lake JM, Chey WD. Testing for Helicobacter pylori in the Clinical Setting. Frontiers in Bioscience 2001; 6: 129-36.

3. Kolts BE, Joseph B, Achem SR, Bianchi T, Monteiro C. Helicobacter pylori detection: a quality and cost analysis. Am J Gastroenterol 1993; 88: 650-5.

4. Gur G, Boyacioglu S, Demirhan B, et al. The importance of increasing the number of gastric biopsies in the diagnosis of Helicobacter pylori. Hepatogastroenterology Journal 1998; 45: 2219-23.

5. Bilgehan H. KlinikMikrobiyoloji, s: 143-6. BarışYayınları, FakültelerKitabevi, 2000. 10. Baskı, İzmir.

6. Henriksson AE, Edman AC, Nilsson I, Bergqvist D, Wadstrom T. Helicobacter pylori and the relation to other risk factors in patients with acute bleeding peptic ulcer. Scand J Gastroenterol 1998; 33: 1030-3.

7. Gönen Ö. Gastrointestinal kanamalar, s: 1060-5. İçinde: illiçin G, Ünal S, Biberoğlu K. Temel İç Hastalıkları. 1996, 1. Cilt, Güneş kitabevi, Ankara.

8. Labenz J, Borsch G. Role of Helicobacter pylori eradication in the prevention of peptic ulcer bleeding relapse. Digestion 1994; 55: 19-23.

9. Jaspersen D. Helicobacter pylori eradication: the best long-term propylaxis for ulcer bleeding reccurence? Endoscopy 1995; 27(8): 622-5.

10. Laheij RJF, Boer WA, Jansen JBM, Lier HJ, Sneeberger PM, Verbeek. AL. Diagnostic performance of biopsy-based methods for determination of Helicobacter pylori infection without a reference standard. J Clin Epidemiol 2000; 53: 742-6.

11. Kaklıkkaya N, Çubukçu K, Aydın F, Yetişkul S, Yazıcı Y, Kapıcıoğlu S. Gastrik biyopsi örneklerinden Helicobacter pylori'nin belirlenmesinde polimeraz zincir reaksiyonunun önemi. İnfek Derg 2001; 15: 307-10. 
12. Misawa K, Kumagai T, Hosogaya S, et al. Clinical and etiological studies of IgG antibodies to Helicobacter pylori detected by enzyme-linked immunosorbent assay. Rinsho Byori 1995; 43(4): 375-80.

13. Luzza $F$, Maletta $M$, Imeneo $M$, et al. Salivary-specific immunoglobulin $G$ in the diagnosis of Helicobacter pylori infection in dyspeptic patients. Am J Gastroenterol 1995; 90(10): 1820-3.

14. Friis L, Engstrand L, Edling C. Prevalance of Helicobacter pylori infection among sewage workers. Scand J Work Environ Health 1996; 22(5): 364-8.

15. Us D, Hasçelik G. Seroprevalance of Helicobacter pylori infection in an Asymptomatic Turkish population. J Infect 1998; 37(2): 148-50.

16. Fraser AG, Scragg R, Metcalf P, McCullough S, Yeates NJ. Prevalance of Helicobacter pylori infection in different ethnic groups in New Zealand children and adults. Aust N Z J Med 1996; 26(5): 646-651.

17. Falk GW. Mide ve Duedonum Hastalıkları, pp: 332-44. Andreoli TE (ed), Cecil Essentials of Medicine. 2001, 5nd ed. Philadelphia.

18. Kocazeybek B, Memişoğlu R, Memişoğlu N, Arıtürk S, Ordu A, Köksal V, ve ark. Helicobacter pylori infeksiyonlarında dışkıda antijen saptama: Tanı ve tedavi sonrası eradikasyonunun izlenmesindeki rolü. İnfek Derg 2003;17:399-403.

19. Naous A, Al-Tannir M, Naja Z, Ziade F, El-Rajab M. Fecoprevalence and determinants of Helicobacter pylori infection among asymptomatic children in Lebanon. J Med Liban 2007; 55(3):138-44.

20. Alim A, Ataş $A D$, Güneş $T$, Ataş M, Yıldırım M, Öztekin A, Yıldızbaş H. Sivas il Merkezinde, Semptomatik ve Asemptomatik Yetişkin Bireylerde Helicobacter pylori Seroprevalansı. C.Ü. Tıp Fak Derg 2004; 26(2): 75-80.

21. Cardenas VM, Dominguez DC, Puentes FA, Aragaki CC, Goodman KJ, Graham DY, Fukuda Y. Evaluation of a novel stool native catalase antigen test for Helicobacter pylori infection in asymptomatic North American children. J Pediatr Gastroenterol Nutr 2008; 46(4): 399-402.

22. Fox JG, Megraud F; Helicobacter, pp: 947-62. In: Murray PR (ed). Manual of Clinical Microbiology. 2009, 9th ed. Volum 1, Ankara.

23. Öztürk H, Şenocak ME, Uzunalimoğlu B, Hasçelik G, Büyükpamukçu N, Hiçsönmez A. Helicobacter pylori infection in symptomatic and asymptomatic children: a prospective clinical study. Eur J Pediatr Surg 1996; 6(5): 265-9.

24. Sandıkçı MÜ, Köksal F. Helicobacter İnfeksiyonları, s: 1005-9. İçinde: Topçu AW, Söyletir G, Doğanay M (editörler), İnfeksion Hastalıkları. 1996, Nobel Tıp Kitabevleri, İstanbul.

25. Perry S, Sanchez ML, Yang S, et al. Gastroenteritis and Transmission of Helicobacter pylori Infection in Households. Emerging Infectious Diseases, www.cdc.gov/eid Vol. 12, No. 11, November 2006.

26. Gulcan EM, Varol A, Kutlu T, ve ark. Helicobacter pylori Stool Antigen Test, Indian J Pediatr 2005; 72: 675-8.

27. Yılmaz Ö, Şen N, Soytürk M, Tankurt IE. Helicobacter pylori tanısında iki farklı dışkı antijen testinin karşılaştırılması, p: 294. XI. Türk Klinik Mikrobiyoloji ve Infeksiyon Hastalıkları Kongresi özet kitabı. 30 Mart-3 Nisan 2003, İstanbul. 
28. Chiba N, van Zanten S, Sinclair P, et al. Treating Helicobacter pylori infection in primary care patients with uninvestigated dyspepsia: the Canadian adult dyspepsia empiric treatment Helicobacter pylori positive (CADET-H. pylori) randomised controlled trial. BMJ 2002; 324: 1012-16.

29. Ozcay F, Kocak N, Temizel IN, et al. Helicobacter pylori infection in Turkish children: comparison of diagnostic tests, evaluation of eradication rate, and changes in symptoms after eradication. Helicobacter 2004; 9: 242-8.

30. Sokucu S, Suoglu OD, Turkkan E, Elkabes B, Ozden T, Saner G. Helicobacter pylori infection in Turkish children with gastrointestinal symptoms and evaluation of serology. Turk J Pediatr 2002; 44: 102-8.

31. Meijer BC, Thijs JC, Kleibeuker JH, et al. Evaluation of eight enzyme immunoassays for detection of immunoglobulin $\mathrm{G}$ against Helicobacter pylori. J Clin Microbiol 1997; 35: 292-4.

32. Salles-Montaudon N, Dertheil S, Broutet N, et al. Detecting Helicobacter pylori infection in hospitalized frail older patients: the challenge. J Am Geriatr Soc 2002; 50: 1674-80.

33. Konstantopoulos N, Rüssmann H, Tasch C, et al. Evaluation of the Helicobacter pylori stool antigen test (HpSA) for detection of Helicobacter pylori infection in children. Am J Gastroenterol 2001; 96(3): 677-83.

34. Cherian S, Burgner DP, Carson CF, Sanfilippo FM, Cook AG, Forbes DA. Diagnosis of Helicobacter pylori infection in a high-prevalence pediatric population: a comparison of 2 fecal antigen testing methods and serology. J Pediatr Gastroenterol Nutr 2008; 47(2):130-5.

35. Agha-Amiri K, Mainz D, Peitz U, Kahl S, Leodolter A, Malfertheiner P. Evaluation of an enzyme immunoassay for detecting Helicobacter pylori antigens in human stool samples. Z Gastroenterol 1999; 37(12): 1145-9.

36. Chen TS, Li FY, Chang FY, Lee SD. Immunoglobulin G antibody against Helicobacter pylori: clinical implications of levels found in serum. Clin Diagn Lab Immunol 2002; 9: 1044-8.

37. Cardenas VM, Dominguez DC, Puentes FA, et al. Evaluation of a novel stool native catalase antigen test for Helicobacter pylori infection in asymptomatic North American children. J Pediatr Gastroenterol Nutr 2008; 46(4): 399-402.

38. Buyukbaba-Boral O, Gonullu N, Anğ-Kucuker M. Dışkı Örneklerinde Helicobacter pylori Antijeninin Saptanmasında ELISA ve İmmunokart Testinin Karşılaştırılması, Turk Mikrobiyol Cem Derg 2004; 34:13-5.

39. Peitz $U$, Leodolter $A$, Kahl $S$, et al. Antigen stool test for assessment of Helicobacter pylori infection in patients with upper gastrointestinal bleeding. Aliment Pharmacol Ther 2003; 17: 1075-84.

40. Erzin Y, Aslan M, Dobrucali A, Altun S, Erdamar S, ve ark. Dispeptik Hastalarda Anti-Helicobacter pylori IgG Elisa Kitinin Helicobacter pylori İnfeksiyonunun Birincil Tanısındaki Etkinliğinin Değerlendirilmesi. İnfek Derg 2007; 21(3): 129-33. 